\title{
AN ANALYSIS OF READABILITY LEVEL OF READING MATERIAL IN ENGLISH TEXTBOOK FOR FIRST GRADE OF SENIOR HIGH SCHOOL
}

\author{
Dzulhijjah Yetti ${ }^{1}$ \\ ${ }^{1}$ UIN Sultan Syarif Kasim Riau, Indonesia \\ Email: ${ }^{1}$ Dzulhijjah@gmail.com
}

Received: 30 Oktober 2019; Accepted 28 Mei 2021; Published 31 Mei 2021

Ed 2021; 2 (1): 1-7

\begin{abstract}
ABSTRAK
Memprediksi tingkat keterbacaan teks bacaan dapat membantu guru untuk mencocokkan teks dengan nilai siswa. Teks bacaan yang tepat diharapkan dapat memudahkan siswa dalam memahami materi. Penelitian ini difokuskan pada tingkat keterbacaan bahan bacaan Bahasa Inggris yang terdapat dalam buku teks Bahasa Inggris berjudul Bahasa Inggris untuk kelas I Sekolah Menengah Atas yang Diterbitkan oleh Pusat Kurikulum dan Buku, Badan Penelitian dan Pengembangan, Kementerian Pendidikan dan Kebudayaan. Penelitian ini mencoba untuk mengetahui apakah bahan bacaan tersebut sesuai atau tidak ditinjau dari tingkat keterbacaan bagi siswa binaan. Penelitian ini menggunakan desain deskriptif kuantitatif. Objek penelitian ini adalah buku teks Bahasa Inggris berjudul Bahasa Inggris Kelas Satu Sekolah Menengah Atas terbitan Kurikulum 2013. Buku ajar terdiri dari lima belas bab yang berisi jenis bahan bacaan seperti dialog dan teks bacaan. Peneliti hanya fokus pada analisis bahan bacaan. Ada tiga macam genre yang ditemukan dalam buku ini, yaitu deskriptif, recount dan narrative. Pengumpulan data dilakukan dengan analisis dokumen. Dalam menghitung tingkat keterbacaan, peneliti menggunakan rumus Flesch Reading Ease (FRE). Hasil penelitian menunjukkan bahwa terdapat 9 teks bacaan dalam buku teks Bahasa Inggris. Dari 9 teks tersebut ditemukan 3 teks deskriptif, 4 teks recount, dan 2 teks naratif. Berdasarkan analisis menggunakan rumus Flesch Reading Ease (FRE), peneliti menemukan bahwa terdapat 3 teks pada level Cukup Mudah, 3 teks pada level Cukup Sulit, dan 3 teks pada level Sulit. Rata-rata teks berada pada level Cukup Sulit $(57,3)$. Berdasarkan teori rumus Flesch Reading Ease (FRE) diketahui bahwa teks berada pada level yang sesuai untuk siswa kelas XI.
\end{abstract}

Kata Kunci: Tingkat Keterbacaan, Bahan Bacaan, Buku Teks.

AN ANALYSIS OF READABILITY LEVEL OF READING MATERIAL IN ENGLISH TEXTBOOK FOR FIRST GRADE OF SENIOR HIGH SCHOOL 


\begin{abstract}
Predicting readability level of reading texts can help the teachers to match the texts with student's grade. The appropriate reading text is expected to ease the students in comprehending the material. This research focused on the readability level of English reading material found in English textbook entitled Bahasa Inggris for first grade of Senior High School Published by Curriculum and Books Center, Research and Development Agency, Ministry of Education and Culture. This study attempts to find out whether the reading materials are appropriate or not in terms of readability level for the target students. This research used descriptive quantitative design. The object of the research is English textbook entitled Bahasa Inggris for First Grade of Senior High School published by Curriculum 2013. The textbook consists fifteen chapters which contained kinds of reading materials such as dialogue and reading texts. The researcher only focuses on analyzing the reading materials. There are three kinds of genre found in this book, they are descriptive, recount and narrative. The data were collected by using document analysis. In calculating readability level, the researcher employed the Flesch Reading Ease (FRE) formula. The results of the study showed that there were 9 reading texts in the Bahasa Inggris textbook. From those 9 texts found that there were 3 descriptive texts, 4 recount texts, and 2 narrative texts. According to the analysis using Flesch Reading Ease (FRE) formula, the researcher found that there were 3 texts in Fairly Easy level, 3 texts in Fairly Difficult level, and 3 texts in Difficult level. In average, the texts are in Fairly Difficult level (57,3). Based on the theory of Flesch Reading Ease (FRE) formula, it is found that the texts are in the appropriate level for tenth grade students.
\end{abstract}

Keyword: Readability level, Reading Material, Textbook.

\title{
INTRODUCTION
}

Textbook are important resources for teaching both productive and receptive skills. It is not surprising that some teacher "use a textbook as the backbone of their courses" (Graves 2000:174). Many beginner teachers lack the experience and confidence to prepare their own materials and to rely on the textbook to ease their burden. Some teachers, experienced and inexperienced, simply follow what is presented in the textbook, while others supplement it by using materials from other textbooks or sources. As Celce Murcia (2001: 381) says that for teachers, using textbook involves, first, the selection of a book, and then, implementing the book in class. Besides considering the criteria of a good textbook based on some experts, the teacher must know the appropriate material in English. To make sure that reading materials are appropriate, teachers have to evaluate the readability level of the reading material before give it to the students. According to DuBay (2004), readability is what makes some texts easier to read than other. It means that readability refers to the difficulty level of the written text based on the level of the students' educational background.

In this research, the researcher analyzed the readability level of reading material that are found on the English mandatory textbook for First grade students of Senior High School in Indonesia based on Curriculum 2013. The textbook used is Bahasa Inggris Textbook written by Utami Widiati, et al. This book is prepared by the government in implementing Curriculum 2013 as the current curriculum in Indonesia. It is important to 
know whether the readability of the reading materials based on students level or not. It is also can be teachers' consideration to keep using this book or wants to find another learning sources which appropriate with students' level. Second, to give information for English teachers that measuring readability level is important because suitable reading texts for students can help them to improve their reading comprehension.

The explanation above shows that it is necessary for the researcher to do this research. It is important evaluating readability level of texts because teachers have to select texts which its readability level appropriate with their students' level or not. Accordingly, the researcher carries out the research entitled "An analysis of Readability level of Reading Material in English Textbook for First Grade of Senior High School”.

\section{METHODOLOGY}

This research used descriptive quantitative design. Gay and Airasian (2000) state that descriptive method is useful for investigating a variety of educational problems and issues. Descriptive studies have an important role in educational research because it greatly increase people's knowledge about what happens in learning process by describing the results in a specific way and reasons using number of scores and tables. In this research, the researcher analyzed the readability level of text by using readability formula. It means that the descriptive quantitative research is in line with the purpose of the research to find out the readability score of the texts and analyzed the level of readability based on its characteristics.

The object of this research was English textbook used in first grade of Senior High School. The book was Bahasa Inggris Textbook written by Utami Widiati, et al. It was published by Curriculum and Books Center, Research and Development Agency, Ministry of Education and Culture. This textbook was claimed to be appropriate with the 2013 curriculum standard. In analyzing the texts, the researcher used Flesch Reading Ease (FRE) to count the readability score of the texts. The English Textbook consisted of 234 pages and 15 chapters. Each chapter was presented in four-skill sections namely Listening, Speaking, Reading, and Writing. Besides, this textbook also took a concern in grammar, pronunciation and vocabulary building. The whole chapters were contained reading materials but only chapter $4,5,810,11,12$, and 13 which were contained the reading text. In this research, the researcher only focused on analyzing reading material. There were no population and sample of the study because all of reading texts in the book are used as the research subject.

\section{RESULT AND DISCUSSION RESULT}

After calculated the data, the researcher found that in average, the result showed that the readability level of reading material in the English textbook entitled Bahasa Inggris Textbook for first grade of senior high school written by Utami Widiati, et al especially in the reading section is in Fairly Difficult level (57.3). It can be concluded that the texts are suitable for first grade of senior high school level based on the theory of Flesch Reading Ease by Rudolf Flesch. The readability score in the average can be seen in the table below: 
Table 4.1 The Average of readability score

\begin{tabular}{|l|l|l|l|l|}
\hline No & Level & $\begin{array}{l}\text { Number of the } \\
\text { Texts }\end{array}$ & $\begin{array}{l}\text { Readability } \\
\text { in Average }\end{array}$ \\
\hline 1 & Fairly Easy & 3 & 73.3 \\
\hline 2 & Fairly Difficult & 3 & 56 \\
\hline 3 & Difficult & 3 & 46.6 \\
\hline & Average & & 57.3 \\
\hline Total & & 9 & \\
\hline
\end{tabular}

Table 4.1 showed that the average of readability score was 57.3 (Fairly Difficult level). It can be concluded that the texts are suitable for first grade of senior high school level based on the theory of Flesch Reading Ease by Rudolf Flesch. Based on the syllabus, there were only three kinds of genre those are learned by the first grade students of senior high school. Those are descriptive, recount and narrative text. The table below showed the readability level of reading material by types of text in the average.

Table 4.5 The Average of Readability score by types of text

\begin{tabular}{|l|l|l|l|}
\hline No & Type of text & Total of the Texts & $\begin{array}{l}\text { Readability } \\
\text { in Average }\end{array}$ \\
\hline 1 & Descriptive & 3 & 52 \\
\hline 2 & Recount & 4 & 53 \\
\hline 3 & Narrative & 2 & 74 \\
\hline & & & \\
\hline
\end{tabular}

Table 4.5 is presented the average readability score of Descriptive text, recount Text, and Narrative text. The average of Descriptive text was 52 (Fairly difficult), the average of Recount text was 53 (Fairly Difficult) and the average of Narrative text was 74 (Fairly Easy). It can be analyzed that if the readability score of a text is higher than other texts, it will be easier to be understood by the students. However, if the readability score of a text is lower than other texts, it will make the text difficult to be understood. It can be concluded that Narrative text was the higher with the readability score 74 that is classified into Fairly Easy and Descriptive text was the lower with the readability score 52 that classified into Fairly Difficult Level.

\section{DISCUSSION}

The Objective of this research is to find out the readability level of reading material in Bahasa Inggris textbook by Utami Widiati, et al for First Grade of Senior High School by using Flesch Reading Ease formula. The analysis of Readability level from 9 texts by Flesch Reading Ease Formula, the table shows the level of 3 texts from the textbook was still in the scope of ideal level of reading materials for First Grade of Senior High School Students with the readability score between 50-60 (Fairly Difficult), 3 texts in the scope of Seventh grade students with the readability score between 70-80 (Fairly Easy), and 3 texts in the scope of College students with the readability score between 30-50 (Difficult). 
But, in average, the readability level of reading material in the English textbook entitled Bahasa Inggris Textbook for first grade of senior high school were in Fairly Difficult level. It can be concluded that based on Flesch Reading Ease, the texts were appropriate and readable for students. However, the score of first grade students of senior high school in reading comprehension is also affected by other factors, besides the textbook. Let's say the teaching method, effort of the students, and the reading practices.

The findings of this research give important information to the teacher and the authors of English textbook on the way how to select and provide good reading materials which are appropriate with the students level. Bad materials can cause a detrimental effect to students' fluency, interest, and motivation (Westwood, 2001). The teacher has to be able to select appropriate reading materials for students so that they can succeed academically (Ehlers-Zavala, 2008).

\section{CONCLUSION}

The research was conducted using Flesch Readability Formula. This research is necessary to finding the level of readability in the textbook. The research was conducted by determining the book, identifying the text, reading the text, and counting the number of the sentences, words, and syllables. After that, the data were analyzed to measure the readability of each text. After analyzing the data of reading texts on the textbook (Bahasa Inggris Textbook for First Grade of Senior High School)by using Flesch Reading Ease, it can be concluded that from 9 reading texts, they are categorized into three levels; Fairly Easy (3 texts), Farly Difficult (3 texts), and Difficult (3 texts). In average, the texts are in Fairly Difficult level. It means that according to the theory of Flesch Reading Ease Formula by Rudolf Flesch, the reading materials are in the appropriate level for First Grade students.

\section{REFERENCES}

Allington, Richard and Michael Strange, Learning Through Reading in the ContentAreas, Lexington: D.C. Heath and Company, 1980.

Brown, Douglas. 2000. Teaching by Principles: An Interactive Approach to Language Pedagogy $2^{\text {nd }}$ Edition. New York: Adision Wesley Longman, Inc.

Celce-Murcia, Marianne, Teaching English as a Second or Foreign Language, Second Edition, Boston: Heinle \& Heinle Publishers, 1991

Collins, K. Thompson. 2014. Computational Assessment of Text Readability: A Survey of Current and Future Research. Ann Arbor, Michigan, U.S.A. 48109.

Dale, Edgar and Jeanne S. Chall. 1949. The Concept of Readability. Elementary English.

DuBay, H. William. 2004. The Principle of Readability: California: Costa Masa.

Ehlers-Zavala, F. P. 2008. Teaching Adolescent Learners in Lenski, S., and J. Lewiss.Reading Success for Struggling Adolescent Learners. New York: The Guilford Press.

Ernawati, Deni. 2013. An Analysis of the Readability Level of Reading Texts in Passport to the World 2 Textbooks by Using Cloze Test. Thesis. Accessed on 10 October 2018. 
Eze, N. J. 2015. Readability of Igbo Language Textbook in use in Nigerian Secondary Schools.ISSN 2222-1735 (Paper) ISSN 2222-288X (Online)Vol.6, No.17, 2015

Flesch, Rudolf. 1949. The Art of Readable Writing: Harper and Row.

Fry, Edward. 1990. A readability formula for short passages. Journal of Reading,

Gay, L.R and Airasian, P. 2000. Educational Research-Competence for Analysis And Application. Sixth Edition. New Jersey: Prentice Hall, Inc.

Grabe, W. 2009.Reading in a Second Language (Moving from Theory to Practice). Cambridge: Cambridge University Press.

Gray, W. S. and B. Leary. 1935. What Makes a Book Readable.Chocago: Chocago University Press.

Graves, Kathleen. 2000. Designing Language Course: A Guide for Teachers. Canada: Heinle\&Heinle Publishers.

Griese, Arnold A. 1977. Do You Read Me? Practical Approaches to Teaching Reading Comprehension. California: Goodyear Publishing Company.

Halliwel, S. 1994. Teaching English in the Primary Classroom. Longman: Elsevier Science Ltd.

Hill, Walter R., Secondary School Reading: Process, Program and Procedures, Boston: Allyn\&Abcon, Inc. 1979.

Hughes, Arthur, Testing for Language Teachers, Second Edition, Cambridge: Cambridge University Press,2003.

Klare, G. R. 1963. The Measurement of Readability. Iowa: Umi Research Press.

McDonough, J., Shaw, C., \& Masuhara, H. (2013). Materials and Methods in ELT: A Teacher's Guide ( $3^{\text {rd }}$ ed.) United Kingdom: John Wiley \& Sons, Inc.

McGrath, I. 2002. Material Evaluation and Design for Language Teaching. Edinburgh: Edinburgh University Press.

Mc Laughlin, G. H. 1969. A new readability formula. Journal of Reading 22: 639-646. SMOG Grading.

Nuttal, Christine. 2000.Teaching Reading Skills in a Foreign Language, Oxford: Heinemann International, 1982.

Orstein, Allan. 1990. Strategies for Effective Teaching. New York: Harper \& Row

Patel, M.F Jain, Prooveen M. 2008. English Language Teaching. Jaipur: Sunrise.

Pikulski, J. J. 2001. Readability. New York: Houghton Mifflin Company.

Renandya, W. A., and Jacobs, G. M. 2008. Extensive Reading: Why Aren't We All Doing it? in Richards, J. C., and Renandya, W. A. Methodology in Language Teaching. New York: Cambridge University Press.

Richards, Jack C., Curriculum Development in Language Teaching, New York: Cambridge University Press, 2001.

Salinger, T., and Campbell, J. 2002. The National Assessment of Reading in the USA in Harrison, C., and Salinger, T. Assessing Reading 1: Theory and Practice. London: Routledge.

Schuldz. 1982. Literature and readability: Bridging the gap in foreign language reading. Modern Language Journal, 65(1):43 - 53.

Siahaan, Sanggam. 2008. The English Paragraph. Yogyakarta: Graha Ilmu. 
Sibanda, L. 2014. The readability of two Grade 4 natural sciences textbooks for South African schools.South African Journal of Childhood Education | 2014 4(2): 154175 | ISSN: 2223-7674.

Smith, Nila Banton, and H. Alan Robinson, Reading Instruction for Today's Children, Second Edition, New York: Prentice-Hall, Inc., 1980.

Sutianah, Wiwin. 2014. The Readability Level of Reading Texts on Advanced Learning English 2. A Thesis.(Accessed on 5 September 2018).

To, Vinh, Fan, Si, and Thomas, Damon. 2013. Lexical Density and Readability: A Case Study of English Textbooks. Issue 67, p. 61-71. (Accessed on 5 September 2018).

Ur, Penny. 2009. A Course in Language Teaching. Cambridge; Cambridge University Press.

Webster, Noah. 1983. Webster's New 20 ${ }^{\text {th }}$ Century Dictionary. New York: Prentice Hall Inc.

Westwood, P. 2001. Reading and Learning Difficulties Approaches to Teaching and Assessment. Victoria: Polar Design Pty Ltd.

Widiati, Utami, et al. 2016. Bahasa Inggris. Jakarta: Pusat Kurikulum dan Perbukuan, Balitbang, Kemendikbud. 